ACTA AGROBOTANICA

Vol. 62 (1): 163-170

2009

\title{
THE EFFECT OF INTERCROPPING ON WEED INFESTATION OF A SPRING BARLEY CROP CULTIVATED IN MONOCULTURE
}

\author{
Ewa Kwiecińska-Poppe, Piotr Kraska, Edward Pałys \\ Department of Agricultural Ecology, University of Life Sciences in Lublin, Akademicka 13, 20-950 Lublin, Poland \\ e-mail: ewa.kwiecinska@wp.pl, piotr.kraska@up.lublin.pl
}

Received: 16.12 .2008

Abstract

This paper presents the results of a study carried out in the years 2005-2007 in the Bezek Experimental Farm near the city of Chełm, Poland, on heavy mixed rendzina soil. The effect of intercropping, using red clover (cv. Dajana) and white clover (cv. Astra), on weed infestation of a spring barley crop was studied. The species composition of weeds in the spring barley crop changed to a small extent under the influence of the application of clover intercropping, whereas the population size of particular species showed large fluctuations. In the spring barley crop with the red clover intercrop, Sonchus arvensis occurred in greatest numbers among dicotyledonous weed species. In the barley crop with white clover and without intercrop, Viola arvensis and Sonchus arvensis were the dominant dicotyledonous species. Setaria pumila was the dominant monocotyledonous species in all the treatments. Intercropping using red and white clover clearly limited the growth and development of weeds. The red clover intercrop in the spring barley crop better reduced the infestation with dicotyledonous weeds and also significantly reduced the number of monocotyledonous weeds and the total number of weeds, whereas the white clover intercrop limited only the number of monocotyledonous weeds. The application of the herbicide Chwastox Extra 300 SL significantly reduced the fresh weight of weeds found in the spring barley crop. The presence of the intercrop resulted in different total numbers of weeds in particular treatments. Intercropping distinctly limited the occurrence of the following weed species: Sonchus arvensis, Fallopia convolvulus, Melandrium album, Amaranthus retroflexus, Veronica arvensis and Medicago lupulina. The investigated intercrop species also reduced the biomass of weeds. The application of the herbicide did not differentiate the number of monocotyledonous weeds, which resulted from the application of Chwastox Extra 300 SL that controls only dicotyledonous species.

Key words: weed infestation, intercropping, weed control

\section{INTRODUCTION}

Many authors indicate the limiting effect of intercropping on the number and weight of weeds. Intercrops compete with weeds for living space, light, nutrients and water. Some intercrop species release allelopathic compounds which limit the occurrence of weeds (D u e r, 1997; O le s z e k, 1994; W a n i c et al. 2004). At the same time, intercrops do not usually affect changes in the species composition of weed infestation. The strength of the impact of intercrops depends on their type and main crop species. Intercropping used for the ploughing-in of the intercrop or for soil mulching improves soil conditions; however, it may cause increased weed infestation of succeeding crops (D u e r , 1996). The use of intercrops is more beneficial than of stubble crops due to the longer period of their remaining in the field and their joint effect, together with cereal crops, against weed development (W a n i c et al. 2005). Intercrops are a factor reducing nitrogen losses in the soil and improving the organic substance balance. The also perform the phytosanitary role, limiting the incidence of diseases and pests of crop plants. They allow biological activity to be maintained and also reduce soil erosion processes ( $\mathrm{M}$ a l i c k i and Michałow s ki, 1994; D u e r, 1996).

According to many authors, appropriately selected herbicides may perform an important role in weed infestation reduction. The introduction of herbicides increases the effectiveness of weed control; it is also a factor which allows negative effects of simplifications in crop rotation to be partially reduced ( $\mathrm{K} \mathrm{u}$ ś et al. 1993; D e r y ł o, 2004).

The aim of the present study was to determine the effect of intercropping on weed infestation of a spring barley crop on rendzina soil in the climatic conditions of south-eastern Poland. 


\section{METHODS}

The experiment was carried out in the years 2003-2005 in the Bezek Experimental Farm near the city of Chełm, Poland, run by the University of Life Sciences in Lublin. The experimental plot was located on medium heavy mixed rendzina soil, formed from chalk rock with the granulometric composition of medium silty loam. This soil had a neutral $\mathrm{pH}$, very high content of $\mathrm{P}-342.1$ and $\mathrm{K}-278.9$, very low magnesium content -16 (values expressed in $\mathrm{mg} \times \mathrm{kg}^{-1}$ of soil), very high organic carbon content - over $3.5 \%$, and it was classified as IIIb soil valuation class and defective wheat complex.

The experiment was conducted in a randomized block design, in four replications, with the plot area of $12 \mathrm{~m}^{2}$. Tillage was performed in accordance with generally accepted agricultural practice recommendations. Seeds dressed with the seed dressing Panoctine 300 LS (a biologically active substance - guazatine in the form of acetate) were sown at an amount of 3.5 million seeds per 1ha. After sowing spring barley, intercrops in the form of red clover cv. Dajana $\left(20 \mathrm{~kg} \times \mathrm{ha}^{-1}\right)$ or white clover cv. Astra (10 kg $\left.\times \mathrm{ha}^{-1}\right)$ were sown manually. The experimental factors were as follows: intercrop species and the method of weed infestation control in the spring barley crop. In the intensive protection variant, the following plant protection agents were used: Chwastox Extra $300 \mathrm{SL} 3.0 \mathrm{l} \times \mathrm{ha}^{-1}$ (MCPA), - (25-29 in the $\mathrm{BBCH}$ scale) - the intercrop at the 3-tiller stage, Alert $375 \mathrm{SC} 1.0 \mathrm{l} \times \mathrm{ha}^{-1}$ (flusilazole + carbendazim) - (20-29 in the BBCH scale), Tango $500 \mathrm{SC} 0.81 \cdot \mathrm{ha}^{-1}$ (tridemorph + epoxiconazole) $-(30-39$ in the $\mathrm{BBCH}$ scale), whereas in the basic variant no herbicide was applied. The plots without intercrop were the control treatment. The following doses of mineral fertilisers were applied: $\mathrm{N}-60 \mathrm{~kg} \times \mathrm{ha}^{-1} ; \mathrm{P}-17.5 \mathrm{~kg} \times \mathrm{ha}^{-1} ; \mathrm{K}$ - $41.5 \mathrm{~kg} \times \mathrm{ha}^{-1}$. Phosphorus and potassium fertilisers as well as $30 \mathrm{~kg}$ of $\mathrm{N} \times \mathrm{ha}^{-1}$ were applied pre-sowing. The remaining part of the nitrogen dose was applied at the shooting stage. Before the harvest of spring barley, the weed infestation was determined using the quantitative gravimetric method. The number and species composition of weeds as well as the fresh weight of the above-ground parts of weeds were determined, based on the sampling sites marked out by a frame with sides of $1 \mathrm{~m} \times 0.25 \mathrm{~m}$, in four randomly selected places on each plot.

The obtained results were statistically analysed by means of variance analysis. The mean values were compared by means of least significant differences using the Tukey test.

Nomenclature of weed species followed $\mathrm{M}$ i r e k et al. (2002).

\section{RESULTS}

The weed species composition in the spring barley crop changed to a small extent under the influence of the application of clover intercropping. In the barley crop, 32 weed species were found, including 26 dicotyledonous and 6 monocotyledonous ones. The population size of particular species showed large fluctuations (Tab. 1). In the spring barley crop with the red clover intercrop, a total of 26 weed species were found, including 21 dicotyledonous and 5 monocotyledonous ones. Among the dicotyledonous species, Sonchus arvensis occurred in greatest numbers, accounting for $10.7 \%$ of total weed species. In the group of monocotyledonous plants, Setaria pumila was predominant, with its percentage share accounting for as much as $55.8 \%$ of all the species (Tab. 1). In the barley crop with the white clover intercrop, 25 weed species were found. Among the 19 dicotyledonous species, Viola arvensis predominated (11.3\% of the community); Sonchus arvensis also occurred in great numbers (8.9\% of total weeds). In the crop without intercrop, 25 dicotyledonous and 5 monocotyledonous weed species were found; Sonchus arvensis was found most frequently, and Viola arvensis also occurred with significant intensity (Tab. 1).

In all the treatments, Setaria pumila was the dominant monocotyledonous species. The weed infestation reduction on the plots with the red and white clover intercrops resulted primarily from the limitation of the occurrence of Setaria pumila by, respectively, 32.7 and $33.2 \%$ as well as of Echinochloa crus-galli by 44.6 and $41.7 \%$, compared to the treatment without intercrop. Intercropping eliminated Thlaspi arvense, Plantago major, Gypsophila muralis, Cerastium holosteoides, Melilotus alba from the community. The reduced numbers of dicotyledonous species can be seen in particular in the spring barley crop with the red clover intercrop. Thanks to its application, the weed infestation with species such as, among others: Sonchus arvensis, Viola arvensis, Stellaria media, Myosotis arvensis, was limited. The white clover intercrop contributed to the reduction in the occurrence of weeds such as: Sonchus arvensis, Melandrium album, Amaranthus retroflexus and Medicago lupulina (Tab. 1).

In the spring barley crop without herbicide application, a total of 31 weed species were found, including 25 dicotyledonous and 6 monocotyledonous ones, whereas in the treatments with the herbicide, this number was 27 species, including 22 dicotyledonous and 5 monocotyledonous ones. In this treatment, a clear reduction in the number of the following species can be seen: Fallopia convolvulus, Stellaria media, Chenopodium album, Cirsium arvense, Papaver rhoeas, Medicago lupulina, Amaranthus retroflexus, 
Table 1

Species composition and number of weeds per $1 \mathrm{~m}^{2}$ of a spring barley crop before harvest, depending on intercrop species (mean for the years 2005-2007).

\begin{tabular}{|c|c|c|c|}
\hline \multirow[b]{2}{*}{ Species } & \multicolumn{3}{|c|}{ Intercrop } \\
\hline & $\begin{array}{l}\text { control without } \\
\text { intercrop }\end{array}$ & red clover & white clover \\
\hline \multicolumn{4}{|l|}{ Dicotyledonous } \\
\hline 1. Sonchus arvensis $\mathrm{L}$. & 8.5 & 4.4 & 4.7 \\
\hline 2. Convolvulus arvensis $\mathrm{L}$. & 1.0 & 1.8 & 1.5 \\
\hline 3. Viola arvensis Murray & 3.9 & 1.5 & 5.9 \\
\hline 4. Fallopia convolvulus (L.) Á. Löve & 2.6 & 1.4 & 2.0 \\
\hline 5. Galium aparine L. & 2.1 & 1.2 & 2.0 \\
\hline 6. Matricaria maritima subsp. indora (L.) Dostál & 1.0 & 1.1 & 2.6 \\
\hline 7. Melandrium album (Mill.) Gracke & 1.0 & 0.5 & 0.3 \\
\hline 8. Stellaria media (L.) Vill. & 2.2 & 0.5 & 2.5 \\
\hline 9. Cirsium arvense (L.) Scop. & 0.3 & 0.5 & 0.0 \\
\hline 10. Chenopodium album $\mathrm{L}$. & 0.8 & 0.4 & 1.1 \\
\hline 11. Polygonum aviculare L. & 0.6 & 0.3 & 0.8 \\
\hline 12. Veronica persica Poir. & 0.1 & 0.3 & 0.4 \\
\hline 13. Anagallis arvensis L. & 0.3 & 0.2 & 0.6 \\
\hline 14. Lamium amplexicaule $\mathrm{L}$. & 0.3 & 0.2 & 0.4 \\
\hline 15. Amaranthus retroflexus $\mathrm{L}$. & 0.4 & 0.2 & - \\
\hline 16. Myosotis arvensis (L.) Hill & 0.4 & 0.2 & 0.7 \\
\hline 17. Veronica arvensis $\mathrm{L}$. & 0.2 & 0.1 & 0.1 \\
\hline 18. Papaver rhoeas $\mathrm{L}$. & 0.3 & 0.1 & 0.4 \\
\hline 19. Medicago lupulina $\mathrm{L}$. & 0.4 & 0.1 & 0.1 \\
\hline 20. Artemisia vulgaris L. & - & 0.1 & - \\
\hline 21. Capsella bursa-pastoris (L.) Medik. & 0.1 & 0.0 & 0.2 \\
\hline 22. Thlaspi arvense $\mathrm{L}$. & 0.1 & - & - \\
\hline 23. Plantago major L. s. str. & 0.1 & - & - \\
\hline 24. Gypsophila muralis L. & 0.1 & - & - \\
\hline 25. Cerastium holosteoides Fr. emend. Hyl. & 0.0 & - & - \\
\hline 26. Melilotus alba Medik. & 0.0 & - & - \\
\hline Total dicotyledonous & 26.8 & 15.1 & 26.3 \\
\hline Number of dicotyledonous species & 25 & 21 & 19 \\
\hline \multicolumn{4}{|l|}{ Monocotyledonous** } \\
\hline 1. Setaria pumila (Poir) Roem. \& Schulz. & 31.9 & 21.3 & 21.5 \\
\hline 2. Avena fatua $\mathrm{L}$. & 0.7 & 1.5 & 0.9 \\
\hline 3. Elymus repens (L.) Gould & 0.2 & 0.4 & 0.7 \\
\hline 4. Apera spica-venti (L.) P. Beauv. & 0.2 & 0.0 & 0.6 \\
\hline 5. Echinochloa crus-galli (L.) P. Beauv. & 2.4 & 0.0 & 1.4 \\
\hline 6. $\quad$ Equisetum arvense L. & - & - & 0.0 \\
\hline Total monocotyledonous & 35.4 & 23.2 & 25.1 \\
\hline Number of monocotyledonous species & 5 & 5 & 6 \\
\hline Total weeds & 62.2 & 38.3 & 51.4 \\
\hline Total number of species & 30 & 26 & 25 \\
\hline
\end{tabular}

0.0 - population size under 0.1

** with Equisetum arvense 
Table 2

Species composition and number of weeds per $1 \mathrm{~m}^{2}$ of a spring barley crop before harvest, depending on the weed control method (mean for the years 2005-2007).

\begin{tabular}{|c|c|c|c|}
\hline \multirow{2}{*}{\multicolumn{2}{|c|}{ Species }} & \multicolumn{2}{|c|}{ Weed control } \\
\hline & & without herbicide & with herbicide \\
\hline \multicolumn{4}{|c|}{ Dicotyledonous } \\
\hline 1. & Sonchus arvensis L. & 5.9 & 5.8 \\
\hline 2. & Viola arvensis Murray & 3.4 & 4.1 \\
\hline 3. & Fallopia convolvulus (L.) Á. Löve & 3.1 & 0.9 \\
\hline 4. & Stellaria media (L.) Vill. & 2.6 & 0.9 \\
\hline 5. & Matricaria maritima subsp. indora (L.) Dostál & 1.8 & 1.3 \\
\hline 6. & Convolvulus arvensis $\mathrm{L}$. & 1.8 & 1.0 \\
\hline 7. & Galium aparine $\mathrm{L}$. & 1.5 & 1.9 \\
\hline 8. & Chenopodium album $\mathrm{L}$. & 1.3 & 0.5 \\
\hline 9. & Polygonum aviculare $\mathrm{L}$. & 0.7 & 0.4 \\
\hline 10. & Melandrium album (Mill.) Gracke & 0.8 & 0.5 \\
\hline 11. & Myosotis arvensis (L.) Hill & 0.6 & 0.3 \\
\hline 12. & Anagallis arvensis L. & 0.5 & 0.2 \\
\hline 13. & Cirsium arvense (L.) Scop. & 0.5 & 0.0 \\
\hline 14. & Papaver rhoeas $\mathrm{L}$. & 0.4 & 0.1 \\
\hline 15. & Lamium amplexicaule $\mathrm{L}$. & 0.3 & 0.2 \\
\hline 16. & Medicago lupulina $\mathrm{L}$. & 0.3 & 0.0 \\
\hline 17. & Amaranthus retroflexus $\mathrm{L}$. & 0.3 & 0.1 \\
\hline 18. & Veronica persica Poir. & 0.1 & 0.4 \\
\hline 19. & Capsella bursa-pastoris (L.) Medik. & 0.1 & 0.1 \\
\hline 20. & Thlaspi arvense $\mathrm{L}$. & 0.1 & - \\
\hline 21. & Artemisia vulgaris L. & 0.1 & - \\
\hline 22. & Gypsophila muralis L. & 0.1 & - \\
\hline 23. & Veronica arvensis $\mathrm{L}$. & 0.0 & 0.3 \\
\hline 24. & Plantago major L. s. str. & 0.0 & 0.0 \\
\hline 25. & Melilotus alba Medik. & 0.0 & - \\
\hline & Cerastium holosteoides Fr. emend. Hyl. & - & 0.0 \\
\hline \multicolumn{2}{|c|}{ Total dicotyledonous } & 26.3 & 19.1 \\
\hline \multicolumn{2}{|c|}{ Number of dicotyledonous species } & 25 & 22 \\
\hline \multicolumn{4}{|c|}{ Monocotyledonous** } \\
\hline 1. & Setaria pumila (Poir) Roem. \& Schulz. & 24.3 & 25.5 \\
\hline 2. & Echinochloa crus-galli (L.) P. Beauv. & 1.5 & 1.1 \\
\hline 3. & Avena fatua $\mathrm{L}$. & 1.0 & 1.0 \\
\hline 4. & Elymus repens (L.) Gould & 0.3 & 0.6 \\
\hline 5. & Apera spica-venti (L.) P. Beauv. & 0.3 & 0.2 \\
\hline & Equisetum arvense $\mathrm{L}$. & 0.0 & - \\
\hline \multicolumn{2}{|c|}{ Total monocotyledonous } & 27.4 & 28.4 \\
\hline \multicolumn{2}{|c|}{ Number of monocotyledonous species } & 6 & 5 \\
\hline \multicolumn{2}{|c|}{ Total weeds } & 53.7 & 47.5 \\
\hline \multicolumn{2}{|c|}{ Number of species } & 31 & 27 \\
\hline
\end{tabular}

0.0 - population size under 0.1

${ }^{* *}$ with Equisetum arvense 
Table 3

Number of dicotyledonous weeds per $1 \mathrm{~m}^{2}$ of a spring barley crop before harvest (mean for the years 2005-2007).

\begin{tabular}{|c|c|c|c|}
\hline \multirow{2}{*}{ Intercrop } & \multicolumn{2}{|c|}{ Weed control method } & \multirow{2}{*}{ Mean } \\
\hline & without herbicide & with herbicide & \\
\hline Red clover & 18.8 & 11.3 & 15.1 \\
\hline White clover & 31.7 & 20.8 & 26.3 \\
\hline Without intercrop & 28.3 & 25.3 & 26.8 \\
\hline Mean & 26.3 & 19.1 & - \\
\hline $\mathrm{LSD}_{0.05}$ & \multicolumn{3}{|c|}{ Intercrops 8.1; weed control method 5.5} \\
\hline
\end{tabular}

Table 4

Number of monocotyledonous weeds per $1 \mathrm{~m}^{2}$ of a spring barley crop before harvest (mean for the years 2005-2007).

\begin{tabular}{lccc}
\hline \multirow{2}{*}{ Intercrop } & \multicolumn{2}{c}{ Weed control method } & Mean \\
\cline { 2 - 4 } & without herbicide & with herbicide & 23.2 \\
\hline Red clover & 23.1 & 23.3 & 25.1 \\
\hline White clover & 29.6 & 20.6 & 35.4 \\
\hline Without intercrop & 29.4 & 41.3 & - \\
\hline Mean & 27.4 & 28.4 & \\
\hline LSD $_{0.05}$ & & Intercrops 8.7 & \\
\hline
\end{tabular}

Table 5

Total number of weeds per $1 \mathrm{~m}^{2}$ of a spring barley crop before harvest (mean for the years 2005-2007).

\begin{tabular}{lccc}
\hline \multirow{2}{*}{ Intercrop } & \multicolumn{2}{c}{ Weed control method } & \multirow{2}{*}{ Mean } \\
\cline { 2 - 4 } & without herbicide & with herbicide & 38.3 \\
\hline Red clover & 41.9 & 34.6 & 51.4 \\
\hline White clover & 61.4 & 41.4 & 62.2 \\
\hline Without intercrop & 57.7 & 66.6 & - \\
\hline Mean & 53.7 & 47.5 & \\
\hline LSD & & Intercrops 12.7 & \\
\hline
\end{tabular}

Table 6

Fresh weight of weeds per $1 \mathrm{~m}^{2}$ of a spring barley crop before harvest (mean for the years 2005-2007).

\begin{tabular}{lcccc}
\hline \multirow{2}{*}{ Intercrop } & \multicolumn{2}{c}{ Weed control method } & Mean \\
\cline { 2 - 4 } & & without herbicide & with herbicide & 79.5 \\
\hline Red clover & 92.1 & 66.8 & 72.9 \\
\hline White clover & 83.0 & 62.8 & 95.1 \\
\hline Without intercrop & 121.6 & 68.5 & - \\
\hline Mean & 98.9 & 66.0 & \\
\hline LSD $_{0.05}$ & & Weed control method 27.3 & \\
\hline
\end{tabular}


Anagallis arvensis, Convolvulus arvensis, Polygonum aviculare, Myosotis arvensis and Lamium amplexicaule (Tab. 2).

In the treatments without chemical protection, a significantly larger number of dicotyledonous weeds was found compared to the plots treated with Chwastox Extra 300 SL. Red clover was the intercrop which better reduced the infestation with dicotyledonous weeds; a significantly smaller number of dicotyledonous weeds was found on the plots with red clover compared to the treatment with white clover and without intercrop (Tab. 3).

Both red clover and white clover significantly limited the number of monocotyledonous weeds before the spring barley harvest compared to the treatment without intercrop. The application of the herbicide did not differentiate significantly the number of monocotyledonous weeds (Tab. 4). The total number of weeds in the spring barley crop before the harvest was significantly lower in the treatments with the red clover intercrop compared to the treatment with white clover and the treatment without intercrop (Tab. 5). The application of the herbicide Chwastox Extra 300 SL significantly decreased the fresh weight of weeds found in the spring barley crop (Tab. 6).

\section{DISCUSSION}

The presented results of the study partially confirm the data contained in literature relating to the significant role of cover crops in weed infestation control ( $\mathrm{Haugga}$ a d-Nielsen et al. 2001; J en sen et al. 2005; W a nic et al. 2005). Differences in their effect are dependent on soil and climatic conditions as well as cereal species. Kuś and Jończy k (2000) as well as Pawłowski and Woźniak (2000) indicate the beneficial effect of intercrops on certain physical, chemical and biological properties of the soil environment, which in turn results in an improvement of growth and development conditions, and what follows, better possibilities of competing with weeds.

The introduction of red and white clover intercrops in this experiment clearly limited the growth and development of weeds. The presence of the intercrop resulted in different total numbers of weeds in particular treatments. The largest amount, 30 species, was found in the spring barley crop without intercrop, whereas in the treatments with the intercrops it was from 25 to 26 species. Thus, intercropping contributed to the impoverishment of the species composition of the weed community in spring barley. It clearly reduced the incidence of the following weeds: Sonchus arvensis, Fallopia convolvulus, Melandrium album, Amaranthus retroflexus, Veronica arvensis and Medicago lupulina. Similar observations were made by $\mathrm{W}$ a $\mathrm{n}$ i c et el. (2004). On the other hand, $\mathrm{W}$ a $\mathrm{n}$ i c et al. (2005) present results in which weed communities in treatments with intercropping, in relation to barley grown in pure culture, were marked by greater species diversity. Both intercrops reduced the population size of weeds, but red clover was more effective in this respect. Malicki and S z y mona (1980/81) demonstrated that intercropping reduces the number and air-dry weight of weeds. $\mathrm{Ha} \mathrm{u} g \mathrm{~g}$ a a r d - N i e l s e $\mathrm{n}$ et al. (2001) and W a n i c et al. (2005) also confirm the limiting effect of intercrops on the growth and development of weeds in a spring barley crop. It results both from the competitive effect of intercropping on weeds and from the effect of allelopathic nature. The strength of this impact depends in particular on the selection of intercrop species. Opposite results were obtained by Kuras zki ew i c z and Pałys (2003) who demonstrated that intercropping did not affect significantly the number and weight of weeds before cereal harvest. Fe led y n-S z e w c z y k and D u e r (2006) also presented results indicating the relatively low weed control activity of intercrops compared to weed control methods used in the conventional and integrated production systems.

Red and white clover intercrops significantly limited the number of monocotyledonous weeds. But the applied weed control methods did not differentiate the level of weed infestation with monocotyledonous weeds, which resulted from the application of the herbicide Chwastox Extra 300 SL that controls only dicotyledonous species.

Pawlonka (2008) presents results showing the weak response of barley to chemical protection against weeds. The greatest effect was obtained by applying a reduced dose $\left(3.0 \mathrm{l} \times \mathrm{ha}^{-1}\right)$ of the herbicide Chwastox Extra 300 SL. In the present experiment, a reduction in fresh weight of weeds in the spring barley crop was observed when chemical treatment was used. De ry 1 o (2004) also found a similar correlation. The abovementioned author did not find any changes in the basic weed species composition under the influence of the applied herbicide, but mainly a decrease in their population.

\section{CONCLUSIONS}

1. The red clover intercrop in the spring barley crop significantly reduced both the number of monocotyledonous and dicotyledonous weeds as well as the total number of weeds, whereas the white clover intercrop limited only the number of monocotyledonous weeds.

2. Intercropping limited the occurrence of the following weeds: Sonchus arvensis, Fallopia convolvulus, Melandrium album, Amaranthus retroflexus, 
Veronica arvensis, Medicago lupulina and Setaria pumila.

3. Setaria pumila, Sonchus arvensis, Viola arvensis were predominant in the spring barley crop and in the intercrops on rendzina soil.

4. The red clover intercrop better reduced the number and fresh weight of weeds in the spring barley crop on rendzina soil compared to the white clover intercrop.

5. In the protection of a spring barley crop using red and white clover intercropping, it is recommended to apply the herbicide Chwastox Extra SL 300, since it significantly limits the number and fresh weight of dicotyledonous weeds.

\section{REFERENCES}

Ad a mczewski K., Matysiak K. (tłumaczenie i adaptacja); 2002. Klucz do określania faz rozwojowych roślin jedno- i dwuliściennych w skali BBCH / Compendium of growth stage identification keys for mono- and dicotyledonous plants. Wyd. I, Inst. Ochr. Roślin: 134.

D e r y ło S.; 2004. Wpływ zróżnicowanej uprawy roli i pielęgnacji roślin na zachwaszczenie łanu jęczmienia jarego. / The effect of differentiated soil tillage and plant cultivation on spring barley infestation. Ann. Univ. Mariae Curie-Skłodowska, Sect. E, (59), 2: 793-800.

Duer I.; 1996. Mulczujący wpływ międzyplonu na plonowanie jęczmienia jarego oraz zawartość wody i azotanów w glebie. / Mulching effect of catch crop on barley yield, soil water and nitrogen storage. Fragm. Agron. 1: 28-43.

D u e r I.; 1997. Fitotoksyczność słomy i resztek pożniwnych pszenicy ozimej uprawianej w monokulturze. / Phytotoxicity of winter wheat straw and post-harvest residue in monoculture Zesz. Probl. Post. Nauk Roln. 452: 59-70.

Feledyn-Szewczyk B., Duer I.; 2006. Efektywność metod zachwaszczenia $\mathrm{w}$ jęczmieniu jarym uprawianym w różnych systemach produkcji. / Effectiveness of weed regulation methods in spring barley cultivated in different crop production systems. Prog. Plant Prot. 46 (1): 45-52.

Hauggaard-Nielsen H., P. A mbus P., Jensen E. S.; 2001. Interspecific competition, $\mathrm{N}$ use and interference with weeds in pea-barley intercropping. Field Crops Research, 70: 101-109.

Jensen E.S., Hauggard-Nielsen H., Kinane J., Andersen M. K., Jornsgaard B.; 2005. Intercropping - the practical application of diversity, competition and facilitationin arable and organic cropping systems; [In:] Researching Sustainable Systems 2005. Proceedings of the First Scientific Conference of the International Society of Organic Agricultural Research (ISOFAR): 22-25.

Kuraszkiewicz R., Pałys E.; 2003. Wpływ wsiewek międzyplonowych na zachwaszczenie łanu roślin ochronnych na glebie lekkiej. / Influence of inter crops on weed infestation of cover crops on light soil. Ann. Univ. Mariae Curie-Skłodowska, Sect. E, 58: 53-67.

Kuś J., Jończyk K., 2000, Regenerująca rola międzyplonów w zbożowych członach zmianowania. / Regenerative potential of oats in long-term cereal crop rotations. Zesz. Prob. Post. Nauk Roln., 470: 49-57.

Kuś J., Siuta A., Mróz A., Kamińska M.; 1993, Możliwość kompensacji ujemnego wpływu stanowiska na plonowanie jęczmienia jarego. / A possibility of compensating a negative effect of stand on spring barley yelding. Pam. Pul., 103: 133-144.

Malicki L., Michałowski Cz.; 1994. Problem międzyplonów w świetle doświadczeń. / Intercrops in experiments Post. Nauk Roln. 4: 3-18.

Malicki L., Szy mon a J.; 1980/81. Zachwaszczenie łanu poplonowych wsiewek traw uprawianych na rędzinie w warunkach deszczowania i zróżnicowanego nawożenia azotem. / Weed infestation of aftercrop grass cultivated on rendzina with watering and varied nitrogen fertilization. Ann. Univ. Mariae Curie-Skłodowska, Sect. E, 35/36: 47-58.

Mirek Z., Piękoś-Mirkowa H., Zając A., Zając M.; 1995. Krytyczna lista roślin naczyniowych Polski. / Flowering plants and pteridophytes of Poland a checklist. Polish Bot. Stud. Guideb. Ser. 15: 1-303.

Oleszek W.; 1994. Brassicacea jako rośliny alternatywne umożliwiające kontrolę zachwaszczenia w rolnictwie zachowawczym. / Brassicacea as alternative plants for weed control in sustainable agriculture. Fragm. Agron. 4 (44): 5-15.

Pawlonka Z.; 2008. Plonowanie jęczmienia jarego w monokulturze przy różnym poziomie ochrony chemicznej przed chwastami. / Spring barley yield in monoculture under differentiated intensity of weed control. Prog. Plant Prot. 48 (1): 307-312.

Pawłowski F., Woźniak A.; 2000. Wpływ wsiewek poplonowych i nawożenia organicznego na plonowanie, zachwaszczenie i zdrowotność pszenżyta ozimego Cz. II. Zachwaszczenie i zdrowotność. / The influence of underplant crop and organic fertilization on field, weed infestation and health state of winter triticale grown in monoculture. Part II. Weed infestation and heath state of triticale. Zesz. Prob. Post. Nauk Roln. 470: 83-89.

Wan ic M., Jastrzębsk a M., Nowicki J.; 2005. Wsiewki międzyplonowe a zachwaszczenie jęczmienia jarego uprawianego w różnych stanowiskach. / Intercropping and weeds growth in spring barley cultivated on different lots. Fragm. Agron. 2 (86): 238-248.

Wanic M., Kostrzewska M., Jastrzębska M., Brzezin G.; 2004. Rola wsiewek międzyplonowych $\mathrm{w}$ regulacji zachwaszczenia jęczmienia jarego w płodozmianach zbożowych. / Role of intercrop sowing in weeds control for spring barley in cereal crops rotation. Fragm. Agron. 1 (81): 85-102. 


\section{Wpływ wsiewek międzyplonowych na zachwaszczenie łanu jęczmienia jarego uprawianego w monokulturze}

\section{Streszczenie}

$\mathrm{W}$ pracy przedstawiono wyniki badań przeprowadzonych w latach 2005-2007 w Gospodarstwie Doświadczalnym Bezek niedaleko Chełma, na ciężkiej rędzinie mieszanej. Badano wpływ wsiewek międzyplonowych w postaci koniczyny czerwonej odmiana 'Dajana' i koniczyny białej odmiana 'Astra' na zachwaszczenie łanu jęczmienia jarego. Skład gatunkowy chwastów w łanie jęczmienia jarego w niewielkim stopniu ulegał zmianom pod wpływem zastosowania wsiewek międzyplonowych koniczyn, natomiast liczebność osobników poszczególnych gatunków ulegała znacznym wahaniom. W łanie jęczmienia jarego z wsiewką koniczyny czerwonej spośród gatunków dwuliściennych najliczniej wystąpił Sonchus arvensis. $\mathrm{W}$ uprawie jęczmienia z koniczyną białą i bez wsiewki dominującymi gatunkami dwuliściennymi były Viola arvensis oraz Sonchus arvensis. Dominującym gatunkiem jednoliściennym we wszystkich obiektach była Setaria pumila. Wprowadzenie wsiewek międzyplonowych w postaci koniczyny czerwonej i białej wyraźnie ograniczało wzrost i rozwój chwastów. Wsiewki międzyplonowe koniczyny czerwonej w łanie jęczmienia jarego lepiej ograniczały zachwaszczenie chwastami dwuliściennymi, zmniejszyły istotnie także liczbę chwastów jednoliściennych i ogółem zaś koniczyny białej tylko liczbę chwastów jednoliściennych. Zastosowanie herbicydu Chwastox Extra 300 SL istotnie zmniejszyło świeżą masę chwastów występujących w łanie jęczmienia jarego. Obecność wsiewki wpływała na zróżnicowaną ogólną liczbę chwastów w poszczególnych obiektach. Wsiewki międzyplonowe wyraźnie ograniczały występowanie następujących gatunków chwastów: Sonchus arvensis, Fallopia convolvulus, Melandrium album, Amaranthus retroflexus, Veronica arvensis i Medicago lupulina. Także biomasę chwastów redukowały badane gatunki wsiewek. Stosowanie herbicydu nie zróżnicowało liczby chwastów jednoliściennych, co wynikało z zastosowania Chwastoxu Extra 300 SL zwalczającego jedynie gatunki dwuliścienne. 